\title{
EXPLORING HYBRIDITY AND MULTICULTURALISM: INTRA AND INTER FAMILY RELATIONS IN ZADIE SMITH'S WHITE TEETH
}

\author{
Irene Pérez Fernández²
}

\begin{abstract}
Zadie Smith's first novel White Teeth (2000) has been analysed as an example of the diverse and multicultural society of the present-day city of London. This essay studies the way in which characters in White Teeth negotiate a sense of belonging and identity and how boundaries are established, and/or violated within that location. It also analyses the characters' hybrid identities and the malleable aspect of that multicultural social space by focusing on the ways Smith depicts spatial configurations of inter and intra family life.
\end{abstract}

Key words: Space, identity, family relations, hybridity, multiculturalism, White Teeth, Zadie Smith.

Explorando el mestizaje y el multiculturalismo: Relaciones intra e interfamiliares en White Teeth de Zadie Smith

Resumen: La primera novela de Zadie Smith, White Teeth (2000), ha sido considerada como ejemplo del multiculturalismo y de la pluralidad que caracterizan hoy en día a la ciudad de Londres. Este artículo estudia los modos en los que los personajes de White Teeth negocian un sentido de pertenencia e identidad y establecen y/o transgreden fronteras espaciales dentro de dicha localización. Este trabajo analiza también la identidad híbrida de los personajes y el carácter maleable que tiene tal espacio multicultural a través del análisis de las relaciones inter- e intra-familiares que se representan en la novela.

Palabras clave: Espacio, identidad, relaciones familiares, hibridismo, multiculturalismo, White Teeth, Zadie Smith.

White Teeth represents a myriad of ethnically, culturally and religiously diverse characters - mainly, Anglo-Jamaican, Bangladeshi and Jewish - adjusting, negotiating and creating a sense of "Britishness" and a sense of belonging in the city of London at three different historical periods of time: the Second World War and post-war years, the period of social changes of the 1980s, and the late 1990s. Critical reviews on White Teeth did not cease to highlight the novel's multiethnic, multiracial and multicultural aspect (Russo 2000; Hanks 2002; Mason 2005). In this respect, the characters in White Teeth are the epitome of hybridity and cultural diversity. Their initial common feature is the shared-spatial locus of the city of London. The spatial dimension is, thus, central to the novel. The metropolis is the backdrop that channels social interaction and becomes the primary space of possibility; a place where a homogeneous and united view of "Britishness" is challenged and where

\footnotetext{
Date of reception: May 2009.

Date of acceptance and final version: July 2009.

2 Contratada Ayudante Doctor; Departamento de Filologia Espanyola, Moderna i LLatina, Universitat de les Illes Balears; $₫$ irene.perez@uib.es.
} 
contesting spatial representations materialise: "It is to the city that the migrants, the minorities, the diasporic come to change the history of the nation ... it is the city which provides the space in which emergent identifications and new social movements of the people are played out" (Bhabha 2004: 243).

The sense of space that White Teeth confers is very close to geographer Doreen Massey's understanding of space as a set of social relations (Massey 1994, 2005). Accordingly, Smith's portrayal of the social configuration(s) of this multicultural space since the early 1940s to the late 1990s can be argued to develop around the networks of relations created with the encounters and dis-encounters of such a variety of characters. The friendship established between Archibald Jones (British) and Samad Iqbal (Bangladeshi) characterises the novel's narrative during the first period of time (the 1940s) and functions as a central axis around which the plot of the novel expands in the other two periods. Their relation is made possible by the disruption of the traditional social order brought about by the Second World War. The years of the aftermath of the Second World War, from 1945 to late 1950s, are considered to be the starting point of a new British society characterised by the presence of citizens of other different ethnicities - mainly those coming from ex-colonial territories - within, up until that moment, an almost completely white social environment (Solomos 1993).

This newly acquired multicultural aspect of Britain is explored in the novel in the subsequent decades. Hence, inter and intra family relations among ethnically-diverse characters are the central motif of the novel during the second period (the 1980s), and the dynamics of inclusion and exclusion in religious and scientific group associations pertain social space in the last part of the novel (the 1990s). In this essay I shall pay close attention to the configurations of social space in the second period of time, the 1980s, a space presented in the novel as evolving around family life. The conservative model of a traditional British family - white, middle-class, protestant - as the pillar of society is put into question in Smith's narrative through the inclusion of other household representations that point towards an inherent multicultural aspect of British society. I shall also concentrate on the novel's critical reception, for, undoubtedly, it has been considered as a landmark in the contemporary British literary panorama.

White Teeth was a huge literary success; what impressed critics the most was the youth of Zadie Smith and the quality of her work. Smith was still an undergraduate student when she was offered a contract by Hamish Hamilton to complete the novel based on the reading of scarcely the first chapter and she wrote the rest of it during her senior year at Cambridge University (Russo 2000: n.p.). The final book was "eagerly anticipated -and extravagantly publicized-this past winter [2000] in London" (O' Rourke 2000: 165). The media described Zadie Smith as the new sensation of the millennium comparing her work to that of Salman Rushdie and Hanif Kureishi (Seltzeer 2000; Merrit 2000; Moss 2000; O'Grady 2000; O'Hagan 2002). O'Rourke, for example, defines Zadie Smith as "an impressive versatile prose stylist, at ease with a variety of voices and breeds of urban slang, and in this and in her panoramic approach to multiculturalism she resembles Salman Rushdie, whose influence is obvious" (O'Rourke 2000: 166).

The overwhelming degree of praise that the novel received is, however, for some critics disproportionate and the product of excessive publicity campaigns (Fowler 2008). The novel has been accused of not giving a very accurate account of British multicultural reality and 
of ethnic identities and ethnic relations in the city of London: "Smith has allowed herself a certain imaginative freedom" (Mullan 2002: n.p.). This imaginative freedom goes hand in hand with a narrative characterised by a multiplicity of characters and cultural references and infused with a great deal of optimism. This style of writing has been described as "hysterical realism" by some (Wood 2001) and as "comic realism" by others (Achenson J. and S. Ross 2005: 109). The former term, coined by James Wood, refers to the style of novels such as White Teeth that try to portray thousands of things at the same time in a manner which is similar to that found in soap operas and situation comedies:

This is not magical realism. It is hysterical realism. Storytelling has become a kind of grammar in these novels; it is how they structure and drive themselves on. The conventions of realism are not being abolished but, on the contrary, exhausted, and overworked. Appropriately, then, objections are not made at the level of verisimilitude, but at the level of morality: this style of writing is not to be faulted because it lacks reality - the usual charge against botched realism - but because it seems evasive of reality while borrowing from realism itself. (Wood 2001: n.p.)

In this respect, Smith herself admits that the novel "could be condemned in certain places for having a sitcom aesthetic" (O'Hagan 2002: n.p.). Moreover, in her review of her own novel Smith wrote that the precocity of herself as a writer had produced a novel which is "the literary equivalent of a hyperactive, ginger-haired tap-dancing 10-year-old" (quoted in Mason 2005: 83). Yet, Smith's novel was admired by a majority of literary critics and readers alike ${ }^{3}$ and it puts forward interesting examples of how spatial configurations in a multicultural society are changed and changing.

There is a "celebratory" attitude towards multicultural relations in the novel that has prompted some literary critics like Dominic Head to consider Smith's work as the epitome of multiculturalism because: "Smith has found a way of harnessing the novel's capacity to embrace heterogeneity, and has used it to give convincing shape to her presentation of an evolving, and genuinely multicultural Britain" (Head 2003: 107). Other critics, such as Jonathan Sell, view White Teeth's model of multiculturalism with a pinch of reserve: "If multiculturality means hybrid identity and the apotheosis of difference, right from the start the novel presented apparently impeccable credentials" (Sell 2006: 28; emphasis added). Sell prefers to consider Smith's depiction of multicultural identities as “particularly appropriate to the subject living in postmodern, multicultural society" (ibid, 2006: 40).

As Smith, the daughter of a Jamaican mother and an English father, admits, the novel creates a space of enjoyment for ethnically-diverse identities:

"It is a kind of fantasy book", [Zadie] agrees. "There is a lot of pessimism currently about race relations in this country. I think the relationships in the book are something to be wished for, but I think they might exist now, and certainly in the future, with the

\footnotetext{
Proof of the former is the fact that with this novel Zadie Smith won three of the most renowned literary prizes in the United Kingdom: the Whitbread First Novel Award, the Guardian First Book Award, the Commonwealth Writers Prizes and two EMMAS, and was shortlisted for a number of other literary prizes and awards such as the Orange Prize for fiction, the Author's Club First Novel Award and the John Llewellyn Rhys Prize.
} 
amount of mixing that has gone on. My generation and my younger brother's generation even more, don't carry the same kind of baggage". (Merrit 2000: n.p.)

White Teeth does not only inscribe what could be, the life of Smith's "generation" of ethnically-diverse individuals in London, but it also attempts to normalise and validate those experiences as a part of common-day life in Britain. Non-arbitrarily, White Teeth sets the background for understanding present-day multiethnic and multicultural British society by establishing a genealogy for British society which moves back to the British colonial period and uncovers, especially in the case of the life of Hortense Bowden, the history of British colonial rule and postcolonial policy. In this respect, the formal structural aspect in the novel complements the opening quotation that reads: "What is past is prologue".

Accordingly, White Teeth is organised following the categories of time and space. The novel is structured in four main blocks using years and characters' names. The years function as concrete time-frame references while each character's name highlights a particular understanding of the historical and spatial location in which they are placed, since the body is a space, the primary location of one's identity (Grosz 1992). In each of these first four structural divisions there are two time references: the first one is the present date in which the characters' life develops and the other is a past date that proffers the characters' historical past, their roots, their origins: i.e. their identity, an identity that far from being essentialist and homogeneous is presented as "myriad and adventitious" and irreducible to "a single cultural sense" (Sell 2006: 34).

Smith addresses the multiplicity of identities and experiences that are to be found in contemporary British society through the inclusion of three different models of family life with their own particular configurations of space. She does not only acknowledge the existence of such "other" spaces but presents them as in an ongoing process of negotiation and change. As Massey argues, recognising the existence of alternative spaces entails the acknowledgment of plurality itself:

The argument is that the very possibility of any serious recognition of multiplicity and heterogeneity itself depends on a recognition of spatiality. The political corollary is that a genuine, thorough, spatialisation of social theory and political thinking can force into the imagination a fuller recognition of the simultaneous coexistence of others with their own trajectories and their own stories to tell. (Massey 2005: 11)

In this sense, Smith's novel unearths the presence of "other" citizens in the city of London when it focuses, from the period of the 1980s onwards, on the plurality of British society by presenting three families of diverse ethnic origin: one Anglo-Jamaican (the Joneses), another Bangladeshi (the Iqbals), and a third one White-Jewish (the Chalfens). These families can be said to account for the main flows of migration groups that came to England from the 1950s onwards: Asian, Afro-Caribbean and European. The first two groups of immigrants were mainly seen as a threat for Britain and, accordingly, a whole discourse on their alienness was built upon them, encouraging their exclusion from the concept of Britishness (Solomos 1993; Jackson 1993). However, the third group, that of Europeans coming mainly from Poland and Ireland, was much more widely accepted and their arrival 
was especially encouraged by the British government from 1945 to 1954, proving that "even at this early stage black migration and settlement was politically perceived in a different way from European migration" (Solomos 1993: 56).

Smith's narrative spreads from a close depiction of family life when it covers the period of time of the 1980s and this fact is not surprising. In the United Kingdom, at that period of time, there was a reassertion of the notion of family as an attempt to counter the disruptions that were taking place at a social level (Smith 1994; Smith 1998). A series of events such as the world-wide oil crisis, the numerous strikes by British miners, together with the economic crisis of late capitalism marked the coming to an end of post-war British stable society. This sense of social instability is portrayed in the novel in the form of three main events: the great hurricane of 15 th October 1987, the Bradford riots against Salman Rushdie's publication of The Satanic Verses on 14th January 1989, and the fall of the Berlin Wall on 10th November 1989 (Smith 2000: 230-243). To counter these disruptions of the "traditional" social order, part of Margaret Thatcher's policy was to appeal to the notion of "common sense" and to put an emphasis on the idea of belonging and the construct of the family.

This prominence given to the idea of belonging during the 1980s rearticulated the divisive boundary of "insider"/ "outsider" in British society:

It is important to note the theme of organicity which underlines this populist construction of British identity. This theme of family, of the organic nature of society, made it very easy to point a finger at the homeless, the blacks and the criminals who are then seen as outsiders. (Sharma 1993: 125; emphasis in the original)

This dichotomy is, however, challenged in White Teeth with the depiction of an "insider" white family, the Chalfens, whose origin is attested to be non-purely British -since they are British and Polish (Smith 2000: 328) - and two other families: that of the Joneses and Iqbals who, by nature of their ethnically-diverse origin, would be considered as "outsiders" but, paradoxically, have members who are proved to be, as in the case of Magid, Samad Iqbal's son, "More English than the English" (ibid: 406).

The Chalfen family is presented as being the true incarnation of Britishness: white, middle-class and educated. The Chalfens' representation suggests that they have internalised the idea of "Britishness" and "belonging". This attitude operates at the beginning, especially with the mother (Joyce), towards Irie and Millat (Archibald and Clara's and Samad and Alsana's daughter and son respectively) when immediately after their first encounter Joyce asks them where they are from: "'you look very exotic. Where are you from, if you don't mind me asking?' 'Willesden' said Irie and Millat simultaneously. 'Yes, yes, of course, but where originally?'... 'Whitechapel,' said Millat, ... 'via the Royal London Hospital and the 207 bus"" (ibid: 319 ; emphasis in the original).

By contrast, the Joneses and the Iqbals' identity statuses derive from a socially-imposed sense of difference and non-belonging. Initially, the fates of Archibald Jones and Samad Iqbal are united during the Second World War when they are located in the same military division. A division formed by five soldiers that are described as abjects in society: "losers; with men like Archie, with men like Dickinson-Smith (whose government file included the 
phrase 'Risk: Homosexual'), with frontal lobotomy cases like Mackintosh and Johnson. The rejects of war. As Roy affectionately called it: The Buggered Battalion" (ibid: 89). Archie is uneducated, he never went to Grammar School, and Samad's characteristic is that, apart from being Asian, he has a dead hand; he is a "cripple" (ibid: 112). Although their racial, sexual, class and physical/mental differences are apparently done away with by the fact that the army hierarchy unifies all soldiers under rank distinctions, they are intrinsically present in that these men were assigned to the same group together. In a way the differences that mark the boundary of their exclusion in a civil society serve as the cementing factor when a disruption of the "normal" social order operates. The bond between both families will strengthen on the basis of their ethnic diversity. The relation between Archibald's wife (Clara) and Samad's wife (Alsana) seems to have been initially imposed by their husbands. Alsana is at first prejudiced against Clara's ethnic origin (ibid: 61), but she gradually realises that their ethnic specificities turn out to be the shared commonality that marks them out in a white environment and will provide them and, especially their children, with a sense of familiarity, home and belonging in the big city of London.

These so-called "insiders" and "outsiders" inhabit a shared location; their children attend the same academic institution and, yet, they are presented as divided by nature of their ethnic and class differences. This hierarchy between the families is socially sanctioned when Irie is forced, together with Millat Iqbal, to go twice a week to the Chalfen's house for an after-school study group with Joshua, the Chalfen's son, as an attempt to "[bring] children of disadvantaged or minority backgrounds into contact with kids who might have something to offer them" (ibid: 308). The first moment of interrelation among the three families is symbolically described as an act of border crossing, questioning ethnic integration and pointing towards social separation between different ethnic groups in British society: "When Irie stepped over the threshold of the Chalfen house, she felt an illicit thrill, ... She was crossing borders, sneaking into England" (ibid: 328; emphasis added). White Teeth, however, moves away from such a binary tendency of thinking about who is considered to be inside or outside the realm of British identity by further exploring the outcomes of multicultural interaction and presenting the three families after the encounters as equally de-stabilised and similarly (dis)placed in the city of London.

For Irie and Millat the encounter with a different family organisation and family relation puts into question their sense of identity and prompts a collapse of their own family boundaries. The Joneses and the Iqbals' senses of unity are fragile, since their families have already been dismantled in a certain way before their encounter with the Chalfens. The Iqbal household is divided the moment Samad separates the twins and sends Magid back to Bangladesh with the hope of strengthening his roots and turning him into a proper Muslim. This separation brings about dramatic effects in the whole family. Millat inhabits an in-between space of self-definition; he lives in a space of indeterminacy: "Millat was neither one thing nor the other, this or that, Muslim or Christian, English or Bengali; he lived for the in-between, he lived up to his middle name, Zulfikar, the clashing of two swords" (ibid: 351). Accordingly, Millat's identity goes through very different phases: he moves from one space of social interaction and definition characterised by a life of misbehaviour (ibid: 
218) with friends and girls outside the home, to start an existence of religious practice and social seclusion after getting involved with KEVIN, a fundamentalist religious organisation. On her part, Samad's wife, Alsana, chooses to carry out a passive action of protest against her son being sent back to Bangladesh against her will. For eight years, she avoids fluid communication with her husband deciding to answer all Samad's queries without precise, specific information (ibid: $213-4$ ).

The Joneses' lack of stability is stressed through Irie's quest for family roots. Irie lacks black referents, apart from her mother, to value the significance of her hybrid identity; she needs a complete family structure, she is looking for a genealogy and a past, roots to support her: "Archie Jones could give no longer record of his family than his father's own haphazard appearance on the planet ... Clara Bowden knew a little about her grandmother ... The rest was rumour, folk-tale and myth" (ibid: 338). In the novel Irie's sense of an extended family is made impossible due to her mother's neglect of Irie's relationship with her grandmother, Hortense Bowden, and the (apparent) lack of ancestors is emphasised by the introduction of an incomplete genealogical tree. Besides, Irie's decision to leave her family home and move to her grandmother's location for a time is prompted by a symbolic turning point in the novel when Irie violates the private space of the conjugal room and discovers that her mother is toothless; her teeth are false. In this act of trespassing space, Irie acknowledges that in order to search for her roots and genealogy she will have to leave her toothless mother and inhabit her grandmother's location for a time.

For the Chalfens, symbolically introduced in the novel with the heading: "Canines: The Ripping Teeth" Millat and Irie are the exotic complement in their existence. Joyce overestimates her role in this new school programme and considers herself to be a kind of saviour for these two teenagers who have gone astray. The Chalfen parents are totally convinced that everything that determines a person's nature is partly in the genes (nature) and partly in nurture. Millat and Irie's family environments are not adequate in Joyce's eyes to allow for the growth of anything fructiferous. This connects with the above-mentioned theme of organicity and is emphasised by Joyce's continuous use of botanic language to refer to human relations in a metaphorical way: "Joyce paused and looked at Irie and Millat the way she had looked at her Gartner Knight delphinium. She was a quick and experienced detector of illness, and there was damage here" (ibid: 324).

The Chalfen family does not tear the apparent unity of Irie and Millat's families apart and remain intact. Interaction is not a one way process and the Chalfens' stability begins to crumble as a consequence of this contact. Irie and Millat develop, thus, from being merely the exotic complement in their idyllic lives to becoming the missing complement in what turns out to be their dull, predictable lives. Millat and Irie's presence evidences the false sense of happiness that is concealed behind the Chalfens' supposedly perfect life. Each of the adult Chalfens establishes a connection with one of the two teenagers that confirms the lack of communication with their own son: whereas Joyce Chalfen develops a devout interest in Millat Iqbal, Marcus Chalfen gets Irie Jones involved with his scientific experiments.

The moment relations are established, boundaries among the three families begin to fade away and new social networks and alternative space(s) of interaction are created. 
Society is made up by the relations that individuals establish; following Massey's theses, space itself should be recognised "as the product of interrelations; as constituted through interactions ... as always under construction" (Massey 2005: 9; emphasis added). In this process social lines of division and integration are constantly drawn and removed and space is moulded and contested. White Teeth engages with this view by presenting different spatial realities in the lives of characters belonging to the same family, the same neighbourhood and the same ethnic community. Examples of this are Samad's obsession with his ancestor Mangal Pande and the fact that nobody else in his family cares about him or the relevance that religion has in the life of Hortense (she is a Jehovah's Witness), which is not passed on to her daughter, Clara, but to one of her boyfriends, Ryan Topps. White Teeth portraits three multicultural families whose members, in despite of belonging to the same family unit, are heterogeneous and with their own stories to tell. This favours the idea that multiculturalism is not a homogeneous concept but a discourse on multiethnicity that accommodates conflicting voices: "Multicultural discourse offers no 'solutions' to the 'problems' resulting from multi-ethnicity, but allows different voices to be heard, different opinions to be expressed" (Sommer 2003: 178).

White Teeth depicts a dynamic representation of the city of London that allows the characters to negotiate and produce alternative spaces. In this sense, White Teeth stresses cultural hybridity and, therefore, celebrates, following Bhabha's thesis, the "Third Space":

which enables other positions to emerge. This third space displaces the histories that constitute it, and sets up new structures of authority, new political initiatives, which are inadequately understood through received wisdom. ... The process of cultural hybridity gives rise to something different, something new and unrecognisable, a new area of negotiation of meaning and representation. (Bhabha 1990: 211)

O'Connell's Pool House is a clear example of such a space; it is Archie's and Samad's place of possibility and its discovery symbolically points towards this fact. Archie is given luncheon vouchers by his boss as a compensation for not being allowed to attend a company meal on a racial basis owing to the fact that his wife, Clara, is black. Archie is, thus, banned from a space on the grounds of his newly acquired mixed identity and he is sent to a space which turns out to be the epitome of hybridity and mixture. Starting from the fact that the name of the place is misleading (since it suggests an Irish pub) and continuing with the fact that it is run by Arabs (which is a subversion of the purest, traditional and essentialist social space of interaction in the United Kingdom), everything in the pub makes it the embodiment of a new space of opportunity; a space that is more than the mixture of Irish pub tradition and Arab history; a space where both and neither are accepted and normalised in the daily lives of the patrons:

The stranger who wanders into O'Connell's Pool House at random, hoping for the soft rise and fall of his grandfather's brogue, perhaps, or seeking to rebound a red ball off the side cushion and into the corner pocket, is immediately disappointed to find the place is neither Irish nor a pool house. He will survey the carpeted walls, the reproductions of George Stubb's racehorse paintings, the framed fragments of some foreign, Eastern script, with no little confusion. He will look for a snooker table and find instead a tall, brown 
man with terrible acne standing behind a counter, frying up eggs and mushrooms. His eye will land with suspicion upon an Irish flag and a map of the Arab Emirates knotted together and hung from wall to wall. (Smith 2000: 183)

The paradox in O'Connell's is that its miscellaneous and diverse origin represents a space of possibility in itself and indeed the patrons form a close community; "a different kind of family" (ibid: 183). Within this community rules of exclusion operate. Membership has to be gained by a process of participation and interaction: "You need to know the place" (ibid, 2000: 183). This need of "knowing the place" is a direct reference to the fact that any production of space, as Henri Lefebvre (1991) points out, entails a social practice that requires a competence on the part of the individual to reproduce and perpetuate that space. Nonetheless, such new spaces of openness and negotiation are characterised by the fact that they continuously move on to "expand the production of knowledge beyond what is presently known" (Soja 1996: 61). This makes it possible for Magid to challenge Mickey's rule of not serving pork and order a bacon sandwich, to his father's disgust (Smith 2000: 450-51), and enables Clara and Alsana to challenge the pub's spatial gender segregation and venture inside together with their husbands on "31 December 1999, that historic night when Abdul-Mickey finally opened his doors to women" (ibid: 541).

The final cathartic space where all the characters are brought together to witness Professor Marcus Chalfen's FutureMouse (C) experiment becomes the ultimate space of possibility. The diversity of characters depicted so far in White Teeth gather together in the last part of the novel around different groups: two religious groups (KEVIN and Jehovah's Witnesses), one scientific (FutureMouse) and one in favour of animal rights (FATE). In a chapter purposely entitled "The Final Space", Smith unites all of them in a common, singular room in the Perret Institute in London conveying the idea that, even if British society is characterised by apparently irreconcilable oppositions, it shares a common social space of identification and interaction. This is a space described as "a new British room, a space for Britain, Britishness, space of Britain, British industrial space cultural space space [sic]" (ibid: 518). The fact that all the characters head to the same point indicates that despite differences, plurality and diversity, there is a common goal, a common place for British society to go to in the new millennium. As Smith writes in her novel: "the end is simply the beginning of an even longer story" (ibid: 540-41). The end of a century will see the beginning of a new era. This idea is emphasised by the fact that the present-day ethnic variety of London is constructed in the novel as the result of an "experiment" that, unlike the FutureMouse $\mathbb{C}$ one, has had enriching outcomes in British society: "this has been the century of strangers, brown, yellow and white. This has been the century of the great immigrant experiment" (ibid: 326).

In conclusion, White Teeth encourages the reader to move away from the opposite binaries of insiders and outsiders and to think about British society in pluralistic terms. In such a setting there is scope for other conceptions of social space. These alternative spaces produced by social diversity challenge a view of space as hosting single, monolithic communities with homogenous identities. London is not only the city where new spaces of interaction among ethnically diverse characters are created but it is also a dynamic 
location that allows for new identity positions to emerge. Identities are presented in White Teeth as extremely malleable. This is particularly visible in the case of second-generation characters. Millat, Magid, Irie and Joshua are continuously negotiating their past family origins, their present circumstances and the prospects for the future. In those situations, everything is possible. They are adjusting to their family and social environment and Smith playfully takes these adjustments to comical extremes: the difficult teenager who turns into a religious fundamentalist while living in London whereas his twin brother, brought up in Bangladesh, becomes a fervent opponent of religion and a science-lover or a responsible and studious son of a respectable scientist who at the end of the novel rejects his father's experiments and becomes an animal rights activist.

Moreover, this new generation of British people challenges British identity in traditional terms: Millat and Magid are Bangladeshi by family but British by birth, and Irie, the representative of a Black-British identity, becomes the future mother of a baby who is a symbol of the ultimate indeterminacy of identity. This baby's genealogical tree not only questions traditional conceptions of Britishness by its ethnic richness, but it also problematises traditional senses of family lineages since in Smith's narrative the biological paternity of the baby will be forever unknown: "because whichever brother it was, it was the other one too" (ibid: 515). Yet, the baby will be brought up by Irie and Joshua "for Irie and Joshua become lovers in the end" (ibid: 541), thus impersonating the final outcome of the interaction of the three families depicted in Smith's narrative.

\section{REFERENCES}

Achenson J. and S. C. E. Ross, eds. 2005. The Contemporary British Novel. Edinburgh: Edinburgh University Press.

Anon. 2000. "In Brief: White Teeth.” The Guardian. http://books.guardian.co.uk/ firstbook2000/story/0,6194,368845,00.html (11 October 2007).

Bнавна, H. K., ed. 1990. Nation and Narration. London and New York: Routledge. 2004. The Location of Culture. London and New York: Routledge.

Fowler, C. 2008. "A Tale of Two Novels: Developing a Devolved Approach to Black British Writing." The Journal of Commonwealth Literature 43: 75-94.

Grosz, E. 1992. "Bodies-Cities.” Sexuality and Space. Ed. B. Colomina. New York: Princeton Architectural Press. 241-253.

Hanks, R. 2002. “The Independent: A New Chapter.” The Independent, 5 Jun.

HeAD, D. 2003. “Zadie Smith's White Teeth: Multiculturalism for the Millennium." Contemporary British Fiction. Ed. R. Lane, R. Mengham and P. Tew. Cambridge: Polity Press.

JACKSON, P. 1993. Maps of Meaning: An Introduction to Cultural Geography. London: Routledge.

Lefebvre, H. 1991. The Production of Space. Oxford and Cambridge: Blackwell. 
Massey, D. 1994. Space, Place and Gender. Minnesota: University of Minnesota Press. 2005. For Space. London: Sage.

Mason, W. 2005. “White Knees: Zadie Smith's novel problem.” Harper's Magazine Oct, 83-88.

Merrit, S. 16 Jan. 2000. "She's Young, Black, British - and the First Publishing Sensation of the Millennium." The Observer. http:// books.guardian.co.uk/departments/ generalfiction/story/0,,12281 (11 October 2007).

Moss, S. 26 Jan. 2000. "White Teeth by Zadie Smith.” The Observer. http://books. guardian.co.uk/critics/reviews/0,,129206,00.html (17 August 2007).

Mullan, J. 2002. “After Post-Colonialism.” The Guardian. http://books.guardian.co.uk/ print/0,,4521793-110738,00.html (11 October 2007).

O’ Grady, K. 2002. "White Teeth: a Conversation with Author Zadie Smith." Atlantis: A Women's Studies Journal. 27, 1: 105-111.

O’Hagan, S. 2002. “Zadie Bites Back.” The Observer. http://books.guardian.co.uk/ departments/generalfiction/story/0,6000,7 (11 October 2007).

O’Rourke, M. 2000. “Fiction in Review.” The Yale Review 88, 3: 159-170.

Russo, M. 27 Apr. 2000. “Girl Wonder: The Life so far of Multicultural Literary Sensation Zadie Smith.” Salon Books. http:/archive.salon.com/books/feature/2000/04/28/ zadie_profile/print (11 October 2007).

Sell, J. P.A. 2006. "Chance and Gesture in Zadie Smith's White Teeth and The Autograph Man: A Model for Multicultural Identity?" The Journal of Commonwealth Literature 41: 27-44.

SEltzer, R. 2000. “White Teeth by Zadie Smith.” http:// www.samizdat.com/isyn/teeth. htlm (11 October 2007).

SHARMA, S. 1993. "Race and the National Question in '80s Britain." Yearbook of Comparative and General Literature 41: 122-131.

Smith, A. M. 1994. New Right Discourse on Race and Sexuality : Britain, 1968-1990. Cambridge: Cambridge University Press.

Sмiтн, S. 1998. The Centre-Left and New Right Divide?: Political Philosophy and Aspects of UK Social Policy in the Era of the Welfare State. London: Ashgate.

Sмith, Z. 2000. White Teeth. London: Penguin.

Soja, E. W. 1996. Thirdspace: Journeys to Los Angeles and Other Real-and-Imagined Places. Oxford; Malden and Victoria: Blackwell Publishing.

Solomos, J. 1993. Race and Racism in Britain. London: Macmillan.

Sommer, R. 2003. “'Simple Survival' in 'Happy Multicultural Land'?: Diasporic Identities and Cultural Hybridity in the Contemporary British Novel." Diaspora and 
Multiculturalism: Common Traditions and New Developments. Ed. M. FLUDERNIK . Amsterdam: Rodopi. 149-181.

Wood, J. 30 Aug. 2001. "Human, All Too Inhuman." The New Republic. http://www. powells.com/review/2001_08_30.html (11 October 2007). 